Louisiana State University LSU Digital Commons

Faculty Publications

Department of Geography \& Anthropology

2015

\title{
Dreaming of Dry Land: Environmental Transformation in Colonial Mexico City
}

Andrew Sluyter

Louisiana State University, asluyter@lsu.edu

Follow this and additional works at: http://digitalcommons.lsu.edu/geoanth_pubs

Part of the Anthropology Commons, and the Geography Commons

\section{Recommended Citation}

Sluyter, Andrew, "Dreaming of Dry Land: Environmental Transformation in Colonial Mexico City" (2015). Faculty Publications. 6. http://digitalcommons.lsu.edu/geoanth_pubs/6

This Article is brought to you for free and open access by the Department of Geography \& Anthropology at LSU Digital Commons. It has been accepted for inclusion in Faculty Publications by an authorized administrator of LSU Digital Commons. For more information, please contact gcoste1@lsu.edu. 


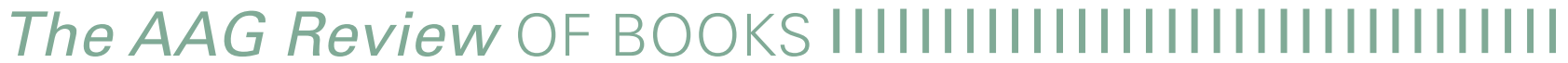

\section{Dreaming of Dry Land: Environmental Transformation in Colonial Mexico City}

Vera S. Candiani. Stanford, CA: Stanford University Press, 2014. xxix and 376 pp., maps, tables, illustrations, notes, index. $\$ 60.00$ cloth (ISBN 9780804788052);

$\$ 48.00$ electronic (ISBN 9780804791076).

\section{Reviewed by Andrew Sluyter, Department of Geography and Anthropology, Louisiana State University, Baton Rouge, LA.}

Geographervs have studied many aspects of the relationship between colonialism and landscape in Latin America. One focus has been on how the Spanish colonizers transformed the precolonial intensive wetland agriculture of the Basin of Mexico by draining its lakes, with continuing consequences for land and life in one of the world's most populous cities. A comprehensive study of the Desagüe de Huehuetoca, the monumental earthwork excavated during the seventeenth and eighteenth centuries to pierce the mountains that entirely enclose the Basin of Mexico and drain the lakes that covered its floor, has nonetheless long remained a gap in that literature. Vera S. Candiani has now filled it with an innovative study that combines approaches developed in historical political ecology, environmental history, and the history of science with incisive analysis of a large body of documents and maps from Mexican and Spanish archives.

Between the fall of the Aztec capital, Tenochtitlán, in 1521 and the beginning of the seventeenth century, landscape transformation had so degraded the precolonial system of dams and canals that the viceregal capital of Mexico City, built on the ruins of its precolonial predecessor, began to suffer periodic inundation. Rather than emulating the Aztecs and their neighbors by modifying the seasonal rhythms of the basin's hydrology, the colonial elite became determined to obliterate them by draining as much of the lake water as possible. Ideally, they hoped, as lake levels rose during the rainy season, the floodwaters would flow through an excavated tunnel or trench that stretched northward for $13 \mathrm{~km}$ from near the village of Huehuetoca, passed through the low mountains that rimmed the northwestern quadrant of the basin, and discharged into the Tula River to ultimately flow down the Pánuco River into the Gulf of Mexico.

Anyone now standing near the eponymous village of Huehuetoca to view the entrance of this anthropic canyon or looking down from any of various viewpoints along its course must, or at least should, feel both wonder and horror. Those who envisioned it were bold and persistent through many generations of construction that lasted from 1607 through the entire eighteenth century. Many of those forced to excavate it suffered horrible hardship and death. And the basin's environment died, too. The lakes that once sustained agricultural productivity, wildlife, and canoe transportation are now nearly entirely gone, while a city of some 23 million inhabitants sinks into its desiccating subsoil, sewage and industrial waste pollute the groundwater, and pumps import more than 600 billion liters of fresh water per year from adjoining watersheds.

Yet, on returning from such a field trip to the Desagüe to search the libraries for a book that explains how such an immense "public engineering project" came into being over the colonial period, the somatic wonder and horror would previously have subsided into intellectual 
disappointment. The sparse literature on the Desagüe has never before done justice to its role in the European colonization of this region.

Now, through eight chapters, Candiani explicates the material and conceptual process involved in a phenomenon that was decidedly immense and colonial but just as decidedly not public, engineered, or a project. In Chapter 1 she sketches the hydraulic expertise of natives in precolonial and early colonial times to contrast it, in Chapter 2, with that of the colonizers. The next five chapters, albeit marred by poor copyediting, detail the process through which the Desagüe came into being over the seventeenth and eighteenth centuries: the contested purposes, designs, and practices as they related to social relations, environmental changes, and landscape transformations. Chapter 8 summarizes and discusses how the Desagüe became such a central actor in the relationship between colonialism and landscape, the establishment of capitalism and modernity, and the dynamic networks of power and knowledge that crisscrossed the Atlantic world.

In doing so, Candiani reconstructs the material dimensions of one of the Atlantic world's largest earthworks, demonstrating excellent understanding of geomorphological and hydrological processes. Forty-nine historical images drawn from the archives illustrate that landscape transformation. Many are maps dating from the sixteenth through nineteenth centuries, some representing the lake system of the entire basin and others focused on the Desagüe and its immediate environs. Others illustrate the details of construction machinery and tools. Still others depict cross-sections, profiles, and plan views of the Desagüe or associated dams, canals, and other water control structures. The few photographs date to the early twentieth century, when many elements of the colonial hydraulic infrastructure remained extant but already seemed like ancient relics in a rapidly industrializing country. Two expertly drafted, original maps synthesize the state of the Desagüe at various times, from its beginnings as a tunnel in 1607 through the end of the colonial period in the early nineteenth century.

In parallel with the material reconstruction, Candiani reconstructs the conceptual dimensions of the Desagüe. For example, friars involved in the construction applied Aristotelian concepts, specifically the qualities of the four elements: earth, water, air, and fire. Such a tunnel or trench, they believed, required a steep gradient to allow a flow sufficient to wet the earth continuously and thereby convert it to liquid and naturally enlarge the excavation as much as necessary. The engineers involved proceed from an entirely different conceptual basis, insisting on careful surveys of the entire basin to measure how much water had to be drained, followed by calculations of discharge rate, gradient, and friction to achieve the greatest drainage efficiency at the lowest construction cost. Meanwhile, natives conscripted to work on the Desagüe incorporated their own knowledge of various types, such as the best plants with which to armor the faces of the earthen dams that channeled runoff into the Desagüe. Such conceptual diversity, often vigorously contested, militated against a cohesive design. Rather than being "engineered" or a "project," the Desagüe emerged as a tangled, contested, punctuated improvisation.

Nor was the Desagüe a "public project," funded by the government to benefit the general populace. Candiani's analysis of the social relations involved demonstrates how some groups controlled and benefited from the Desagüe, principally the landed elite of the city. Others bore the costs, especially the conscripted native workers who built it, but also rural landowners who relied on seasonal inundation to dress fields with an increment of fertilizing mud. Curiously, unlike so many other aspects of life and land in colonial Mexico, enslaved Africans played little role in the Desagüe.

Notably, Candiani weaves the whole into a narrative alive with individuals who range from friars, viceroys, and engineers to native laborers, foremen, and local officials. One of the most captivating passages recounts how a Flemish military engineer and the royal cosmographer inspected the original tunnel in late November 1614. The cosmographer, Enrico Martínez, had proposed the tunnel to the viceroy and directed its excavation by 60,000 forced laborers over 1607 and 1608, but its cost and poor performance prompted the Crown to send the engineer, Adrain Boot, to investigate. Martínez, Boot, a notary to record their observations, and a translator entered the tunnel in canoes paddled by natives. Sometimes they proceeded on the shoulders of the natives, crawled on planks supported by the vaulting, or waded through water up to their waists. The "air was dank and filled with danger and echoes" (p. 73). With a quadrant, plumb bob, and staff, they surveyed the gradient of the tunnel, sighting by torchlight and memorizing their observations until they could emerge "after nightfall, drenched and muddy," to record them and make calculations (pp. 72-73).

The archives also record the perspectives of natives, perhaps more briefly but no less poignantly. In a case dating to the eighteenth century, a local magistrate arrived in 
a village to draft laborers. They would be forced to dig while dangling from ropes down the walls of the Desagüe to convert the tunnel into an open trench. The harsh and dangerous work had consumed so many native lives over two centuries that they derisively referred to the Desagüe as the Trench of Misfortunes. In this case, one repeated many times as native resistance grew to labor conscription, the magistrate and his troop entered the village quietly to surprise the men. Finding them playing cards he ordered them to "get up in the name of the King" (p. 277). But one, Lorenzo Baca, jumped up wielding his knife, dashed for the door, and escaped with several others while shouting "Out of the way, carajo $\left(f^{* *} k\right)$ !"
The Desagüe itself, however, emerges as one of the dominant actors in the colonization of Mexico. Without romanticizing a precolonial society beset with its own evils, Candiani shows how the Desagüe converted a system of productive agriculture, integrated transportation, and domestic water supply and drainage into a (post)colonial dystopia made inhabitable only through unsustainable energy inputs. The Desagüe controlled nature to protect private property from flooding at the expense of the commons, converting social capital into private capital. And it helped to establish modernity's conceit: a fallacious belief in the double emancipation that supposedly freed society from nature and individuals from society. 